\title{
EFFECTS OF MATERNAL EDUCATION, PSYCHOSOCIAL STRESS, NUTRITIONAL STATUS AT PREGNANCY, AND FAMILY INCOME, ON BIRTHWEIGHT IN NGANJUK, EAST JAVA
}

\author{
Dhewi Nurahmawati1,2), Harsono Salimo3), Yulia Lanti Retno Dewi4) \\ 1)Academy of Midwivery PGRI, Kediri, East Java \\ 2)Masters Program in Public Health, Sebelas Maret University \\ 3)Department of Pediatrics, Dr. Moewardi Hospital, Surakarta \\ 4)Department of Nutrition, Faculty of Medicine, Sebelas Maret University
}

\begin{abstract}
Background: Low birthweight (LBW) is one of the primary causes of infant mortality. It shares $27 \%$ of infant mortality rate (IMR). The Indonesian Demographic and Health Survey in 2007 reported that the IMR was 34 deaths per 1,000 live births. As much as 30.3\% of this rate was accounted by LBW. As such LBW is an important global public health issue. Countries arround the world have committed to overcome this problem. This study aimed to investigate the effects of maternal education, psychosocial stress, nutritional status at pregnancy, and family income, on birthweight.

Subjects and Method: This was an observational analytic study with case control design. The study was conducted in Ngetos community health center, Nganjuk, East Java, from May to June, 2017. A total sample of 120 were selected for this study by fixed disease sampling, compresing 40 infants with low birthweight and 80 infants with normal birthweight. The dependent variable was birthweight. The independent variables were maternal education, psychosocial stress, nutritional status at pregnancy (middle-upper arm circumference, MUAC), maternal anemia, and family income. MUAC was measured by MUAC measuring tape. Hemoglobin concetration was measured by Sahli meter. Psychosocial stress was measured by Holmes and Rahe stress scale. The other variables were measured by a set of questionnaire. Path analysis was used for data analysis.

Results: $\mathrm{MUAC} \geq 23.5 \mathrm{~cm}(\mathrm{~b}=-0.80, \mathrm{SE}=0.57 ; \mathrm{p}=0.064)$, hemoglobin concetration $\geq 11 \mathrm{~g} / \mathrm{dL} \quad(\mathrm{b}=-120.16, \mathrm{SE}=45.14, \mathrm{p}=0.008)$, and low psychosocial stress $(\mathrm{b}=-0.80, \mathrm{SE}=0.57, \mathrm{p}=0.164)$ directly and negatively affected low birthweight. Maternal education $\geq$ Senior High School $(b=1.28$, $\mathrm{SE}=0.056, \mathrm{p}=0.022)$, psychosocial stress $(\mathrm{b}=-0.001, \mathrm{SE}<0.001, \mathrm{p}=0.097)$, and family income $(\mathrm{b}=0.97, \mathrm{SE}=0.46, \mathrm{p}=0.036)$ positively affected MUAC. MUAC $\geq 23.5 \mathrm{~cm}$ positively affected hemoglobin concentration $\geq 11 \mathrm{~g} / \mathrm{dL}$ ( $\mathrm{b}=$ $0.19, \mathrm{SE}=20.84, \mathrm{p}<0.001)$.
\end{abstract}

Conclusion: MUAC, hemoglobin concetration, and low psychosocial stress directly and negatively affect low birthweight.

Keywords: low birthweight, MUAC, maternal anemia, psychosocial stress, family income

Correspondence: Dhewi Nurahmawati. Masters Program in Public Health, Sebelas Maret University, Jl. Ir. Sutami 36 A, Surakarta 57126, Central Java. Email: dhenoura@gmail.com. Mobile: +62813330787826. 